\section{The science community must unite over Iraq}

SIR - Members of the international scientific community are deeply disturbed by the systematic murder of several hundred academics in Iraq, the recent mass kidnapping at the Ministry of Higher Education's Research Directorate (see "Gunmen seize academics at Baghdad ministry" Nature 444, 252-253; 2006) and the consequent threat to close all the universities in Baghdad.

Recent assassinations have included that of Isam Kadhem F. al-Rawi, a geology professor at the University of Baghdad. Al-Rawi refused to join the estimated 2,000 Iraqi scientists thought to have fled the country (see Nature 441, 1036-1037; 2006). Instead, he remained and was a candidate for minister of higher education and scientific research. He monitored and publicized the plight of academics in Iraq and had compiled and maintained a list of his colleagues who were victims of hit squads - a list that al-Rawi now joins.

Local and international authorities must ensure that scientists and academics in Iraq are protected. In July, ICSU, the International Council for Science, issued a statement condemning the violence in Iraq (www.icsu. org/9_latestnews/latest_19.html). ICSU's new Committee on Freedom and Responsibility in the conduct of Science, of which I am chairman, now urges international organizations to join ICSU in searching for ways to bring this aggression against Iraqi scientists to an end, and to express solidarity with them.

Science is a global endeavour. When its fundamental values and principles are undermined and scientists are discriminated against or maltreated, it is not only science, but society as a whole, that suffers.

Bengt Gustafsson

Department of Astronomy and Space Physics, Uppsala University, Box 515, SE-751 20,

Uppsala, Sweden

\section{German societies want to keep an international voice}

SIR - In the News in Brief story "German science academy stumbles at birth" (Nature $444,14 ; 2006)$, it is reported that I wrote a "last-minute protest letter" opposing plans for the establishment of a national science academy. However, the Max Planck Society, together with all major German research organizations, supports the current plans for setting up such an academy.

The representative role of the proposed academy on an international level had been extensively discussed. It had been agreed that, for any specific case, German science should be represented by the organization with either the highest competence for the issue or the best organizational fit to the international body in question. This implies that some representational activities will stay with a funding council or a research organization.

It therefore came as a surprise to the research organizations that the states commission had been advised to constitute the academy as a body with a general power to represent German science internationally.

As a consequence, the German Research Organizations wrote a clarifying letter to the states commission, which - as president of the Max Planck Society I signed also on behalf of the heads of Germany's research-funding agency the DFG, the Fraunhofer Society, the Leibniz Association, the Helmholtz Association of German research centres and the German Rectors' Conference.

Peter Gruss

Max Planck Society, Hofgartenstraße 8, 80539 München, Germany

\section{Imagine projects with a strong emotional appeal}

SIR - Your Editorial “To build bridges, or to burn them" (Nature 443, 481; 2006) concludes that a large group of environmentalists "might be more likely to change their minds about science if its practitioners would desist from sneering at emotional argument and demonstrate that science is a window through which we can see our world more clearly".

I would go further, and argue that scientists would do well to use emotion, based on sound science, in that demonstration.

Our Imagine programme (www. foundation-imagine.org) involves scientists and high-school students working together on tangible projects for application in developing countries. Scientists submit their ideas, from which small groups of students aged 16 to 18 each choose one. The student groups then draft a business plan, carry out experiments, obtain local information and outline budgets, while considering social issues.

The winning team sees its plan carried out: in 2004 the production of biodiesel from algae in Mozambique; in 2005 extraction of avocado oil in Kenya; and in 2006, redevelopment of a plantation in Suriname to produce colouring compounds.

Imagine's emotive collaboration of schoolchildren and scientists working on applications in developing countries appeals to the media, and hence to a very broad audience that might not otherwise be reached.

Patricia Osseweijer

Kluyver Centre for Genomics of

Industrial Fermentation,

Delft University of Technology,

Julianalaan 67, 2628 BC Delft, The Netherlands

\section{Religious authorities overrule scientists in Iran}

SIR - Your Editorial support for the recent rise in scientific productivity in Iran is admirable ("Revival in Iran" Nature 442, 719; 2006).

However, I disagree with the comments made by the country's health minister Kamran Lankarani in Correspondence ("Iran seeks nuclear power to replace reliance on oil” Nature 443, 906; 2006) about how to help those scientists who struggle to perform quality research there. The minister did not comment, for example, on President Ahmadinejad's recent call for students to demand the removal of liberal and secular university lecturers (see news.bbc.co.uk/1/hi/world/middle_ east/5316634.stm).

The theocracy ruling Omar Khayyam's country is no friend of free scientific inquiry. Consider this: each year, the month-long Ramadan fast is meant to end with a festival at the next new moon. But the fast cannot end until the Shia authorities have made an official observation of the lunar crescent to check the astronomers' calculations. This year, for some reason, the official observation could not be carried out in time, so religion's mistrust of science paralysed the country's social life for several days.

Kamran Behnia

Ecole Supérieure de Physique et de Chimie Industrielles, 10 Rue Vauquelin,

75005 Paris, France

\section{One small point}

SIR - Will the nano hazard symbol reported in News in Brief (Nature 443, 737; 2006)

come with a free magnifying glass with which to read it?

Rupert C. Marshall

Institute of Biological Sciences, University of Wales, Aberystwyth, Edward Llwyd Building,

Penglais, Aberystwyth,

Ceredigion SY23 3DA, UK

Contributions to Correspondence may be submitted tocorres@nature.com.They should be no longer than $\mathbf{5 0 0}$ words, and ideally shorter. Published contributions are edited. 